\section{Casa Diamante} Entreríos, Argentina
Esta vivienda, retiro para una pareja que vuelve a su lugar de origen, se localiza en un mirador sobre las barrancas orientales del río Paraná. El rigor del clima y la flexibilidad para recibir invitados son los detonantes de la reducción de desplazamientos internos y la flexibilidad de adaptación. El sistema constructivo es conocido y probado en el medio, por lo que se recurre a mano de obra tradicional que maneja el ladrillo cocido. La planta en forma de T define espacios servidos y servidores, privilegiando las vistas del estar, el estudio y los dormitorios. Planta y cubierta se unen a través de muros-tamices de ladrillo, velando y cualificando el paisaje en el interior.

Jorge Marsino Arquitecto, Universidad Ricardo Palma María Inés Buzzoni Arquitecta, Universidad de Chile Claudio Santander Arquitecto, Universidad de Chile

Jorge Marsino, María Inés Buzzoni
This home a retreat for a couple returning to their place of origin, is located on a lookout over the eastern cliffs of the Parana River. The intensity of the climate and flexibility to receive visitors are the triggers for reducing the internal movement and the adaptability. The building system is a known and proved system in the industry so that traditional workmanship is used for the baked brick. The plan and roof are united using brick screen-walls, sifting and qualifying the landscape in the interior.

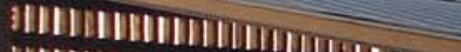

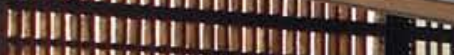

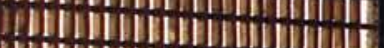 ititutitititiof

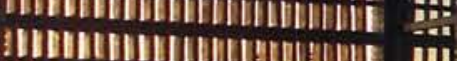

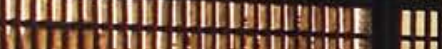 III)

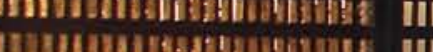 IIIII III

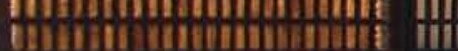

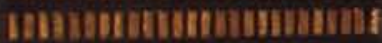



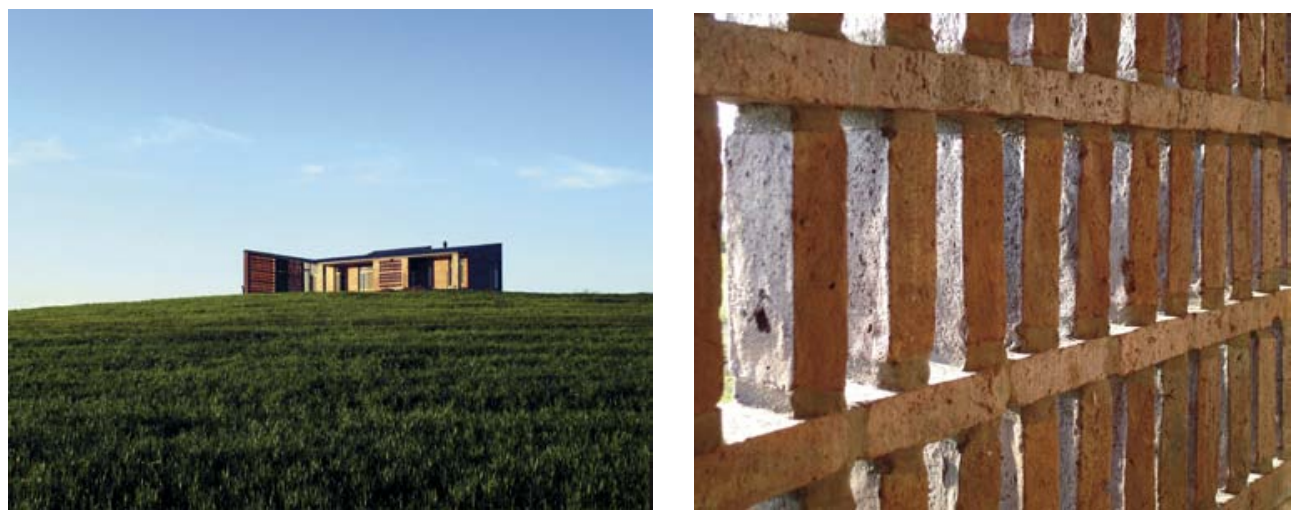

CASA DIAMANTE

Arquitectos Jorge Marsino, María Inés Buzzoni, Claudio Santander Colaborador Raúl Brunatti (Argentina) Ubicación Diamante, Entreríos, Argentina Cliente Jorge Marsino, Cecilia Prado Cálculo estructural Luis Gaitán Construcción Horacio Kapp Materialidad estructura de muros dobles de albañilería de ladrillo cocido reforzada con pilares y cadenas de hormigón armado, revestimientos interiores en pintura y cerámica esmaltada, pavimentos exteriores e interiores de pastelones cerámicos, ventanas de aluminio anodizado y cristales termopanel Presupuesto 10,3 uf $/ \mathrm{m}^{2}$ (US\$ $440 / \mathrm{m}^{2}$ ) Superficie terreno 8 há Superficie construida 305,2 m² Año proyecto 2005 Año construcción 2005-2006
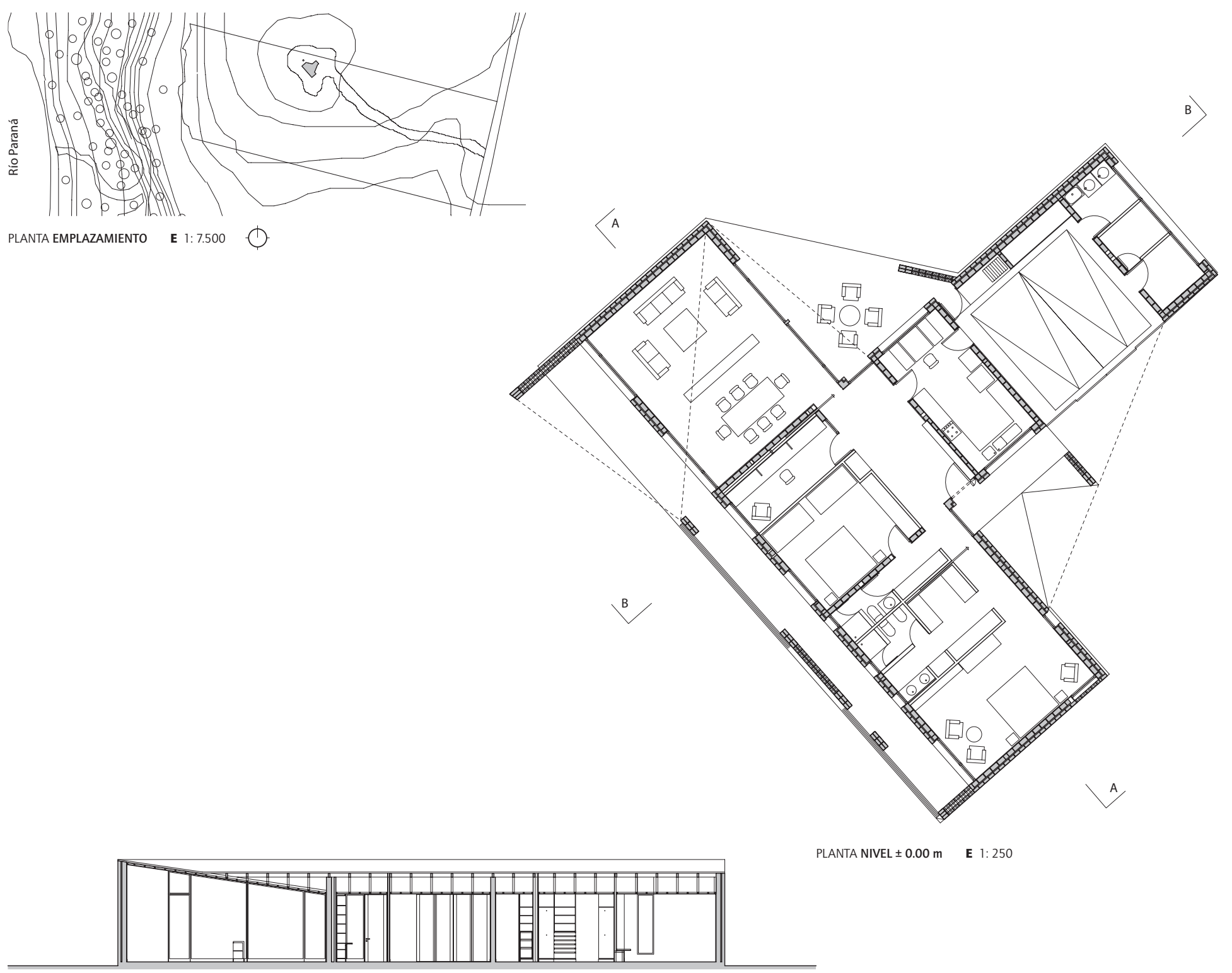

PLANTA NIVEL $\pm 0.00 \mathrm{~m} \quad$ E $1: 250$

CORTE AA E 1:250

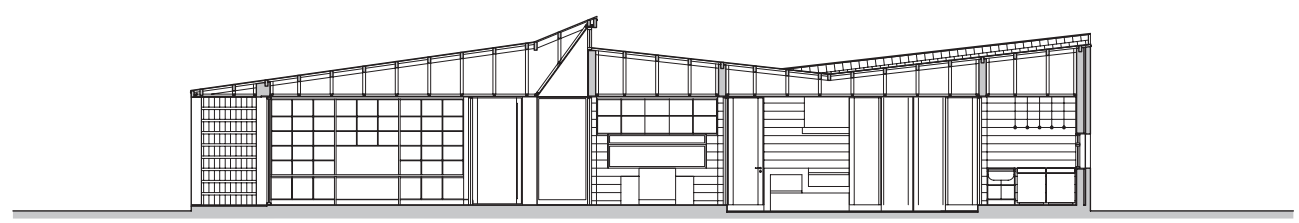

CORTE BB 